\title{
Pengungkapan Islamic Social Reporting pada Perusahaan di Jakarta Islamic Index
}

\section{Disclosure of Islamic Social Reporting among Companies in Jakarta Islamic Index}

\author{
Khaerun Nissa Rizfani ${ }^{1}$, Deni Lubis ${ }^{2}$ \\ ${ }^{1}$ Departemen Ilmu Ekonomi Syariah, Institut Pertanian Bogor 16680, email: rizfanissa0920@gmail.com \\ ${ }^{2}$ Departemen Ilmu Ekonomi Syariah, Institut Pertanian Bogor 16680, email: denilubis@gmail.com
}

\begin{abstract}
Islamic Social Reporting (ISR) is a benchmark for reporting Islamic-based social performance to companies. However, the development of ISR is currently not growing rapidly in Indonesia because there are no regulations that regulate sharia social responsibility reporting standards. Increased disclosure of Islamic social performance is expected to influence the decisions of muslim investors in choosing sharia shares in companies listed in the Jakarta Islamic Index. This study aims to analyze corporate social responsibility (CSR) disclosures in sharia and the factors that influence them. The data used are annual reports of companies registered in JII from 2012 to 2015, 14 of which were selected from 30 companies. The method used in this study is panel data regression with the fixed effect model (FEM) approach. The results of the analysis show that of the five variables that allegedly influence the level of ISR disclosure, three variables, namely company size have a positive effect, firm age and leverage have a significant negative effect on ISR disclosure. The other two variables, namely the number of board of commissioners and profitability have no effect on ISR disclosure.
\end{abstract}

Keywords: Firm age, firm size, ISR disclosure, leverage, panel data

\begin{abstract}
Abstrak. Islamic Social Reporting (ISR) merupakan tolok ukur pelaporan kinerja sosial berbasis Islami pada perusahaan-perusahaan. Namun demikian, perkembangan ISR saat ini belum berkembang pesat di Indonesia karena belum ada regulasi yang mengatur standar pelaporan tanggung jawab sosial secara syariah. Peningkatan pengungkapan kinerja sosial Islami diharapkan memengaruhi keputusan investor muslim dalam memilih saham syariah di perusahaan yang terdaftar di Jakarta Islamic Index. Penelitian ini bertujuan untuk menganalisis pengungkapan tanggung jawab sosial perusahaan secara syariah dan faktorfaktor yang memengaruhinya. Data yang digunakan adalah laporan tahunan perusahaan yang terdaftar di JII dari tahun 2012 hingga 2015, terpilih sebanyak 14 dari 30 perusahaan. Metode yang digunakan dalam penelitian ini adalah regresi data panel dengan pendekatan fixed effect model (FEM). Hasil analisis menunjukkan bahwa dari lima variabel yang diduga memengaruhi tingkat pengungkapan ISR, tiga variabel, yaitu ukuran perusahaan berpengaruh positif, umur perusahaan dan leverage berpengaruh negatif signifikan terhadap pengungkapan ISR. Dua variabel lainnya, yaitu jumlah dewan komisaris dan profitabilitas tidak berpengaruh terhadap pengungkapan ISR.
\end{abstract}

Kata kunci: Data panel, leverage, pengungkapan ISR, ukuran perusahaan, umur perusahaan

\section{PENDAHULUAN}

Suatu perusahaan tidak cukup memfokuskan diri pada pertumbuhan ekonomi semata, melainkan membutuhkan pembangunan yang berkelanjutan. Pembangunan berkelanjutan adalah cara pandang mengenai kegiatan yang dilakukan secara sistematis dan terencana untuk peningkatan kesejahteraan masyarakat, kualitas kehidupan, dan lingkungan umat manusia tanpa mengurangi akses dan kesempatan kepada generasi yang akan datang untuk menikmati dan memanfaatkannya.

Dalam perkembangannya, pembangunan berkelanjutan umumnya diaktualisasikan pada praktik Corporate Social Responsibility (CSR) atau Tanggung Jawab Sosial Perusahaan. CSR merupakan sebuah komitmen perusahaan atau dunia bisnis untuk berkontribusi dalam pengembangan ekonomi yang berkelanjutan dengan memperhatikan tanggung jawab sosial perusahaan dan menitikberatkan pada keseimbangan antara perhatian terhadap aspek ekonomi, sosial, dan lingkungan (Maali et al., 2006). 
Fitria dan Hartanti (2010) menjelaskan bahwa di Indonesia, kesadaran mengenai CSR terlihat dari semakin banyaknya unit-unit bisnis yang melaporkan praktik CSR dalam laporan keuangan tahunan maupun press release lainnya. Pengungkapan CSR tidak lagi bersifat sukarela, melainkan merupakan bagian dari kewajiban beberapa perusahaan yang diatur dalam Undang-Undang Nomor 40 Tahun 2007 tentang Perseroan Terbatas yang disahkan pada tanggal 20 Juli 2007. Pengungkapan CSR merupakan bagian pertanggungjawaban suatu perusahaan terhadap amanah dari Allah sehingga menjalankan perusahaan harus sesuai dengan cara dan tujuan syariah.

Othman et al. (2009) melakukan penelitian mengenai praktik pelaporan CSR perusahaan syariah yang terdaftar di bursa Malaysia dan hasilnya memperlihatkan bahwa pelaporan masih banyak pada tahap konseptual. Hal ini disebabkan belum adanya standar yang dapat diadopsi perusahaan dalam penerapan CSR syariah. Penelitian dalam ranah CSR syariah umumnya menggunakan model indeks Islamic Social Reporting yang dikembangkan dengan standar pelaporan berdasarkan AAOIFI (Accounting and Auditing Organization for Islamic Financial Instutions). Secara khusus indeks ISR adalah perluasan dari social reporting yang meliputi harapan masyarakat tidak hanya mengenai peran perusahaan dalam perekonomian, tetapi juga peran perusahaan dalam perspektif spiritual (Haniffa, 2002).

Merina dan Verawaty (2016) melakukan penelitian tentang komparasi indeks Islamic Social Reporting perusahaan perbankan syariah dan perusahaan go public yang teradftar di Jakarta Islamic Index (JII). Penelitian ini menggunakan pengujian statistik Mann Whitney Test untuk membandingkan enam kategori pada indeks ISR antarkedua kelompok sampel. Hasil penelitian ini menunjukkan bahwa perusahaan perbankan syariah mengungkapkan Islamic Social Reporting (ISR) Index lebih baik dibandingkan dengan perusahaan listing di JII berdasarkan kriteria Pendanaan dan Investasi, Karyawan, Masyarakat, Lingkungan, dan Tata Kelola Perusahaan, terkecuali untuk Produk dan Jasa dimana nilai perusahaan perbankan syariah dan perusahaan JII hanya berbeda tipis $15.76 \%$. Hasil penelitian membuktikan bahwa pengungkapan yang dilakukan oleh perusahaan yang beroperasi dengan konsep syariah, seperti perbankan syariah ternyata lebih memenuhi indeks ISR dibandingkan perusahaan konvensional non perbankan syariah, seperti perusahaan-perusahaan yang listing di JII.

Farook et al. (2011) melakukan penelitian tentang mengembangkan dan menguji model teoritis dari faktor-faktor penentu pengungkapan sosial bank-bank Islam. Hasil penelitian menunjukkan bahwa represi politik dan sipil, proporsi penduduk muslim, IG-SCORE, Investment Acount Holders (IAH), dan ukuran perusahaan berpengaruh signifikan terhadap pengungkapan tanggung jawab sosial perusahaan Bank Syariah. Sampel yang digunakan sebagian besar berasal dari negara-negara Timur Tengah, yaitu Bahrain, Kuwait, Saudi Arabia, Turki, UEA, Qatar, dan Yaman. Penelitian yang dilakukan oleh Darus et al. (2014), hanya dua bank syariah di Indonesia yang terus melakukan peningkatan dalam ISR di Indonesia, yaitu Bank Mandiri Syariah dan Bank Muamalat selama lima tahun terakhir, walaupun belum memuat seluruh komponen pelaporan. Sementara aspek kesesuaian syariah tidak memiliki pengaruh yang signifikan terhadap pengunkapan ISR di Indonesia.

Pelaksanaan CSR yang semakin meningkat, keinginan untuk membuat pelaporan sosial yang bersifat syariah (Islamic Social Reporting atau ISR) seharusnya semakin besar. Dalam perspektif Islam, CSR merupakan konsekuensi dari ajaran Islam. Tujuan dari syariah Islam (maqashid syariah) adalah maslahah, sehingga kegiatan bisnis diupayakan untuk menciptakan maslahah bukan sekedar mencari keuntungan. Hal ini berkaitan dengan keputusan investor dalam memilih produk investasi syariah di perusahaan. Berdasarkan data Bursa Efek Indonesia (2017), jumlah investor syariah yang tercatat sebanyak 15,141 mewakili 2.7\% dari total investor di BEI yang berjumlah 568,752 dan jumlah investor syariah dibanding total investor bertambah signifikan dari angka $0.7 \%$ atau 2,705 dari total investor 364,465 dihitung sejak akhir 2014.

Rama dan Meliawati (2014) mengatakan bahwa tujuan utama dari pelaporan sosial secara syariah adalah untuk menunjukkan kepatuhan perusahaan-perusahaan terhadap syariah. Tujuan lain dari pelaporan perusahaan seperti yang dikenal dalam model Barat, yaitu untuk membantu pengambil keputusan dalam membuat keputusan ekonomi. Namun dalam perspektif Islam, ini adalah tujuan 
sekunder. Implikasinya adalah bahwa bisnis syariah harus mengungkapkan semua informasi yang diperlukan untuk memberikan informasi kepada masyarakat tentang kegiatan operasional mereka. Dengan kata lain, konsep pengungkapan berkaitan erat dengan konsep akuntabilitas. Sementara perbankan syariah dan peningkatan jumlah CRS terus tumbuh dan berkembang (Mallin et al., 2014), Namun menurut penelitian yang dilakukan oleh Nobanee dan Ellili (2015) dari tahun 2003 hingga 2013 mendapatkan bahwa pengungkapan ISR di perbankan syariah masih jauh di bawah perbankan konvensional.

Berdasarkan latar belakang di atas menunjukkan bahwa diperlukan pelaporan sosial secara syariah oleh perusahaan-perusahaan sebagai pertanggungjawaban kepada Allah dan masyarakat. Di samping itu, dibutuhkan pula penjelasan faktor yang berpengaruh signifikan terhadap pengungkapan ISR. Penelitian akan difokuskan pada kelompok perusahaan yang terdaftar di JII tahun 2012 sampai 2015. Pemilihan kelompok perusahaan ini didasarkan pada alasan bahwa saham syariah di perusahaan JII yang tercatat di BEI memiliki rata-rata nilai kapitalisasi terbesar dan nilai likuiditas perdagangan paling tinggi. Hal ini menunjukkan minat investor terhadap saham syariah di perusahaan JII tinggi sehingga perusahaan akan mengungkapkan kegiatan operasionalnya secara lebih luas untuk meyakinkan pengambilan keputusan para investor dalam memilih suatu saham syariah.

\section{KAJIAN TEORI}

\section{Teori Agensi}

Menurut Jensen dan Meckling (1976), kepentingan manajemen dan pemegang saham seringkali bertentangan, sehingga dapat terjadi konflik antara keduanya. Hal tersebut disebabkan karena manajer mengutamakan kepentingan pribadi. Sebaliknya, pemegang saham kurang setuju dengan kepentingan pribadi manajer karena pengeluaran tersebut akan menambah biaya perusahaan dan menyebabkan penurunan keuntungan perusahaan serta penurunan dividen yang diterima. Konflik kepentingan antara manajer dan pemegang saham dapat diminimumkan dengan suatu pengawasan yang dapat menyejajarkan kepentingan tersebut. Namun, munculnya mekanisme pengawasan ini menyebabkan timbulnya suatu biaya yang disebut agency cost. Salah satu sudut pandang dari teori agensi adalah conflict resolution hypothesis yang menyatakan bahwa perusahaan menggunakan kegiatan CSR untuk mengurangi potensi konflik antara manajer dan pihak lainnya termasuk pemangku kepentingan, yang akhirnya bisa meningkatkan nilai perusahaan sehingga dapat mengurangi biaya agensi (agency cost reduction).

\section{Pengungkapan (Disclosure)}

Purnomosidhi (2006) dalam penelitiannya mengungkapkan suatu kerangka untuk kepentingan pengungkapan sukarela berdasarkan informasi yang dibutuhkan investor didasari oleh Laporan Jenkin (AICPA, 1994), yaitu data keuangan dan non keuangan, analisis data keuangan dan non keuangan, informasi yang berorientasi pada masa depan, informasi tentang manajer dan pihak-pihak yang berkepentingan terhadap perusahaan, latar belakang perusahaan, serta dimensi modal intelektual. Sejalan dengan penelitian yang dilakukan oleh Platonova et al. (2018) menunjukkan bahwa pengungkapan CSR sangat berhubungan dengan performa keuangan di masa depan dan memiliki pengaruh yang baik terhadap performa keuangan lembaga tersebut dalam jangka panjang. Menurut PSAK Nomor 1 Ayat 74, informasi mengenai manajemen dan pemegang saham yang meliputi susunan nama anggota direksi dan komisaris merupakan pengungkapan wajib. Begitu pula halnya dengan latar belakang perusahaan yang meliputi tujuan perusahaan dan bidang usaha utama perusahaan merupakan pengungkapan wajib. Sementara studi Lestari (2013) menyimpulkan bahwa faktor yang memengaruhi ISR, yaitu ukuran perusahaan, keuntungan, umur perusahaan, dan jumlah dewan komisioner. Semakin besar ukuran perusahaan maka dampak pengungkapan ISR-nya semakin baik. Keuntungan bedampak positif terhadap level pengungkapan ISR. Sementara umur perusahaan tidak berdampak signifikan terhadap pengungkapan ISR, dan semakin banyak jumlah dewan komisioner tidak berdampak signifikan terhadap pengungkapan ISR. El-Halabya (2015) melakukan penelitian tentang pengungkapan pelaporan ISR di seluruh perbankan syariah di dunia dan menemukan bahwa ada 
hubungan positif antara level pengungkapan CSR dan standar akuntansi, tipe auditor, ukuran bank, dan keberadaan departemen auditor syariah.

\section{Corporate Social Responsibility (CSR)}

Menurut Saidi dan Abidin (2004), setidaknya ada empat model atau pola penerapan CSR yang biasanya diterapkan oleh perusahaan di Indonesia, yaitu keterlibatan langsung, melalui yayasan atau organisasi sosial perusahaan, bermitra dengan pihak lain, serta mendukung atau bergabung dalam suatu konsorsium. Menurut Ambadar (2008), penerapan CSR memberi manfaat kepada perusahaan dalam hal: (1) pembentukan citra positif dari masyarakat sehingga perusahaan dapat tumbuh dan berkelanjutan, (2) perusahaan lebih mudah memperoleh akses terhadap modal, (3) perusahaan dapat mempertahankan sumber daya manusia (SDM) yang berkualitas, dan (4) perusahaan dapat meningkatkan pengambilan keputusan pada hal kritis dan memudahkan pengelolaan risiko.

\section{Islamic Social Reporting (ISR)}

Haniffa (2002) mengatakan bahwa tujuan dari ISR adalah (1) sebagai bentuk akuntabilitas kepada Allah SWT dan masyarakat, (2) meningkatkan transparansi kegiatan bisnis dengan menyajikan informasi yang relevan dengan memerhatikan kebutuhan spiritual investor muslim atau kepatuhan syariah dalam pengambilan keputusan. Bentuk akuntabilitas yang dimaksud, seperti (a) menyediakan produk yang halal dan baik, (b) memenuhi hak-hak Allah dan masyarakat, (c) mengejar keuntungan yang wajar sesuai dengan prinsip Islam, (d) mencapai tujuan usaha bisnis, (e) menjadi karyawan dan masyarakat, (f) memastikan kegiatan usaha yang berkelanjutan secara ekologis, dan (g) menjadikan pekerjaan sebagai bentuk ibadah. Sementara itu, bentuk transparansinya adalah (a) memberikan informasi mengenai semua kegiatan halal dan haram dilakukan, (b) memberikan informasi yang relevan mengenai pembiayaan dan kebijakan investasi, (c) memberikan informasi yang relevan mengenai kebijakan karyawan, (d) memberikan informasi yang relevan mengenai hubungan dengan masyarakat, dan (e) memberikan informasi yang relevan mengenai penggunaan sumber daya dan perlindungan lingkungan. Ada lima tema pengungkapan Indeks ISR menurut Haniffa (2002), yaitu Tema Pendanaan dan Investasi, Tema Produk dan Jasa, Tema Karyawan, Tema Masyarakat, dan Tema Lingkungan Hidup. Kemudian dikembangkan oleh Othman et al. (2009) dengan menambahkan satu tema pengungkapan, yaitu tema Tata Kelola Perusahaan.

\section{Jakarta Islamic Index}

Tahapan atau seleksi untuk memilih kriteria pemilihan saham yang masuk dalam indeks syariah, termasuk saham di Jakarta Islamic Index menurut Sudarsono (2003), antara lain: (1) memilih kumpulan saham dengan jenis usaha utama yang tidak bertentangan dengan prinsip syariah dan sudah tercatat lebih dari tiga bulan, kecuali masuk 10 besar dalam hal kapitalisasi, (2) memilih saham berdasarkan laporan keuangan tahunan atau tenaga tahun terakhir yang memiliki rasio kewajiban terhadap aktiva maksimal sebesar 90\%, (3) memilih 60 saham dari susunan saham di atas berdasarkan urutan rata-rata kapitalisasi pasar terbesar selama satu tahun, dan (4) memilih 30 saham dengan urutan berdasarkan tingkat likuidasi rata-rata nilai perdagangan reguler selama satu tahun terakhir.

\section{Umur Perusahaan}

Umur perusahaan diperkirakan memiliki pengaruh terhadap pengungkapan Islamic Social Reporting. Semakin panjang umur perusahaan akan memberikan pengungkapan informasi yang lebih luas. Alasan yang mendasarinya berkaitan dengan Teori Agensi, dimana perusahaan yang memiliki pengalaman lebih dalam pengungkapan laporan tahunan akan lebih mengetahui kebutuhan informasi perusahaan yang dapat mengurangi asimetri informasi (Marwata, 2001). Omar dan Simon (2011) membuktikan bahwa terdapat hubungan yang positif antara umur perusahaan dengan tingkat pengungkapan kinerja sosial, sedangkan penelitian Oktavianti dan Wahidahwati (2014) menemukan bahwa terdapat hubungan yang negatif antara umur perusahaan dengan tingkat pengungkapan. 


\section{Dewan Komisaris}

Salah satu tugas dewan komisaris adalah memberikan laporan mengenai pelaksanaan tugas pengawasan dan pemberian nasihat yang dilakukan dalam laporan tahunan serta menelaah dan menyetujui laporan tahunan tersebut. Dewan komisaris sebagai pihak yang independen dan netral dalam perusahaan diharapkan mampu menjembatani adanya asimetri informasi yang terjadi antara pihak pemilik dengan pihak manajer dengan mendorong anggota dewan komisaris lain untuk melakukan tugas pengawasan lebih baik lagi. Jika pengawasan telah dilakukan secara efektif maka pengelolaan perusahaan akan dilakukan dengan baik dan manajemen akan mengungkapkan semua informasi yang ada (White et al., 2007). Penelitian Wulan dan Anggraini (2015) membuktikan bahwa terdapat hubungan yang positif antara jumlah dewan komisaris dengan tingkat pengungkapan ISR. Menurut Khoirudin (2013) ukuran dewan komisaris dan ukuran dewan pengawas syariah berpengaruh positif terhadap pengungkapan Islamic Social Reporting perbankan syariah di Indonesia. Sementara menurut Rahman dan Bukair (2013) atribut kombinasi dewan pengawas syariah memberikan dampak signifikan terhadap pengungkapan CSR.

\section{Leverage}

Leverage timbul karena perusahaan dalam operasinya menggunakan aktiva dan sumber dana yang menimbulkan beban tetap bagi perusahaan. Penggunaan aktiva yang menimbulkan beban tetap disebut dengan operating leverage, sedangkan penggunaan dana dengan beban tetap disebut financial leverage (Sudana, 2011). Diamond (1991) menyatakan bahwa tingginya tingkat suku bunga utang dapat mendorong kreditur untuk berperan aktif dalam mengawasi perusahaan (manajemen). Zweibel (1996) menyatakan bahwa saat perusahaan mempunyai utang bunga yang tinggi, kemampuan manajemen berinvestasi lebih pada program laporan pertanggungjawaban sosial perusahaan adalah terbatas. Teori mereka mendukung bahwa leverage yang tinggi memiliki hubungan negatif dengan tingkat pengungkapan. Sementara itu, penelitian Andrikopoulos et al. (2014) menemukan semakin besar perusahaan dan semakin tinggi leverage maka kemungkinan perusahaan akan memberikan informasi tentang CRS akan lebih tinggi.

\section{Profitabilitas}

Profitabilitas menggambarkan kemampuan perusahaan mendapatkan laba melalui semua kemampuan dan sumber daya yang ada. Manajer ingin meyakinkan kepada pemilik atau investor tentang profitabilitas yang dapat dicapai agar mereka meningkatkan kompensasi untuk manajer, sehingga manajemen melakukan pengungkapan yang lebih luas (Hikmah et al., 2011). Penelitian Omar dan Simon (2011) membuktikan bahwa terdapat hubungan yang positif antara profitabilitas dengan tingkat pengungkapan ISR. Sementara penelitian Naser dan Hassan (2013) menemukan bahwa ukuran perusahaan, industri, dan keuntungan memengaruhi pengungkapan ISR.

\section{Ukuran Perusahaan}

Ukuran perusahaan dapat diukur dengan total aktiva. Semakin besar total aktiva, maka semakin besar pula ukuran perusahaan tersebut, karena semakin banyak modal yang ditanamkan. Suhardjanto dan Wardhani (2010) mengatakan bahwa ukuran perusahaan merupakan prediktor yang memengaruhi tingkat sosial ekonomis yang besar terhadap lingkungannya, sehingga lebih menjadi sorotan pemangku kepentingan. Maka dari itu, perusahaan dituntut untuk semakin banyak mengungkapkan informasi, termasuk mengenai kinerja sosial perusahaan. Penelitian Adelopo (2011) serta Naser dan Hassan (2013) membuktikan bahwa terdapat hubungan yang positif antara ukuran perusahaan dengan tingkat pengungkapan ISR.

\section{Hipotesis}

Berdasarkan kajian teori dan penelitian terdahulu tentang Islamic Social Reporting, maka dapat disusun hipotesis penelitian sebagai berikut:

1 Umur perusahaan signifikan positif terhadap tingkat pengungkapan ISR $\left(\mathrm{H}_{1}\right)$.

2 Jumlah Dewan Komisaris signifikan positif terhadap tingkat pengungkapan ISR $\left(\mathrm{H}_{2}\right)$. 
3 Leverage signifikan negatif terhadap tingkat pengungkapan ISR $\left(\mathrm{H}_{3}\right)$.

4 Profitabilitas signifikan positif terhadap tingkat pengungkapan ISR $\left(\mathrm{H}_{4}\right)$.

5 Ukuran perusahaan signifikan positif terhadap tingkat pengungkapan ISR $\left(\mathrm{H}_{5}\right)$.

\section{METODE}

\section{Jenis dan Sumber Data}

Data pada penelitian ini menggunakan data sekunder berupa laporan tahunan dan laporan keberlanjutan yang diterbitkan oleh perusahaan yang terdaftar dalam Jakarta Islamic Index pada Bursa Efek Indonesia. Sumber data lainnya juga diperoleh dari Otoritas Jasa Keuangan, Bursa Efek Indonesia, buku, jurnal, dan laman resmi tiap perusahaan. Data yang digunakan merupakan data panel. Data time series (deret waktu) meliputi data dari tahun 2012 sampai 2015. Data cross section (kerat lintang) ditentukan sejumlah 14 perusahaan dari 30 perusahaan yang terdaftar di Jakarta Islamic Index dengan menggunakan purposive sampling, yaitu pemilihan sampel berdasarkan pertimbangan karakteristik yang cocok berkaitan dengan tujuan menjawab penelitian. Adapun kriteria yang dijadikan pertimbangan adalah sebagai berikut:

1 Perusahaan yang listing secara konsisten di JII selama periode Desember 2012 - November 2016.

2 Perusahaan yang menerbitkan laporan tahunan untuk periode berakhir 31 Desember 2012 hingga 2015.

3 Perusahaan yang menggunakan mata uang Rupiah.

\section{Metode Pengolahan dan Analisis data}

Metode penilaian indeks ISR dilakukan dengan menggunakan scoring, dimana nilai 0 jika tidak ada pengungkapan terkait item indeks ISR dan nilai 1 jika ada pengungkapan terkait item tersebut. Metode analisis data yang digunakan pada penelitian ini adalah metode regresi data panel dengan pendekatan Fixed Effect Model (FEM). Pengolahan dilakukan dengan menggunakan software Eviews 9 dan Microsoft Excel. Variabel independen dalam penelitian ini adalah umur perusahaan, jumlah dewan komisaris, leverage, profitabilitas, dan ukuran perusahaan. Variabel dependennya adalah Islamic Social Reporting (ISR). Taraf nyata (a) dalam penelitian ini adalah 5\% dan $10 \%$.

\section{Data Panel}

Data panel adalah gabungan antara data deret waktu dan data kerat lintang. Menurut Widarjono (2007), untuk mengestimasi parameter model dengan data panel terdapat tiga teknik yaitu Model Common Effect (CEM), Model Efek Tetap (Fixed Effect Model), dan Model Efek Random (Random Effect Model). Ada tiga uji untuk memilih teknik estimasi data panel. Pertama, uji statistik F digunakan untuk memilih antara metode CEM atau metode FEM. Kedua, uji Hausman yang digunakan untuk memilih antara metode FEM atau metode REM. Ketiga, uji Lagrange Multiplier (LM) digunakan untuk memilih antara metode CEM atau metode REM. Model persamaan data panel yang digunakan dalam penelitian ini adalah sebagai berikut:

$$
\mathrm{ISR}_{\text {it }}=\alpha+\beta_{1} \mathrm{AGE}_{\mathrm{it}}+\beta_{2} \mathrm{DK}_{\mathrm{it}}+\beta_{3} \mathrm{LEVERAGE}_{\mathrm{it}}+\beta_{4} \mathrm{PROFIT}_{\mathrm{it}}+\beta_{5} \mathrm{SIZE}_{\mathrm{it}}+\varepsilon_{\mathrm{it}}
$$

\section{Keterangan:}

$\begin{array}{ll}\text { ISR }_{\text {it }} & : \text { Indeks pengungkapan ISR } \\ \text { AGE }_{\text {it }} & : \text { Umur perusahaan, selisih antara tahun penelitian dengan tahun IPO (first issue) } \\ & \\ \text { DK }_{\text {it }} & : \text { di BEI (tahun) } \\ \text { LEVERAGE }_{\text {it }} & : \text { Leverage, rasio total liabilitas terhadap total aset } \\ \text { PROFIT }_{\text {it }} & : \text { Profitabilitas, rasio laba bersih terhadap total ekuitas } \\ \text { SIZE }_{\text {it }} & : \text { Ukuran perusahaan, natural logaritma dari total aset } \\ \alpha & : \text { Intersep } \\ \beta & : \text { Nilai koefisien variabel }\end{array}$




$\begin{array}{ll}\mathrm{i} & : \text { Data kerat lintang 14 perusahaan } \\ \mathrm{t} & : \text { Data deret waktu tahun } 2012 \text { hingga } 2015 \\ \varepsilon & : \text { Error term }\end{array}$

\section{Uji Asumsi Klasik}

Uji asumsi klasik terdiri dari empat uji, yaitu uji normalitas, uji heteroskedastisitas, uji multikolineritas, dan uji autokorelasi. Uji normalitas dilakukan untuk menguji apakah nilai residual yang telah terstandarisasi pada model regresi berdistribusi normal atau tidak. Uji heteroskedastisitas bertujuan untuk menguji apakah dalam model yang terbentuk terjadi ketidaksamaan varian dari residual model regresi. Uji multikolinieritas bertujuan untuk menguji apakah dalam model regresi yang terbentuk ada korelasi yang tinggi atau sempurna di antara variabel bebas. Uji autokorelasi bertujuan untuk mengetahui apakah ada korelasi antara anggota serangkaian data observasi yang diurutkan menurut waktu atau ruang.

\section{HASIL DAN PEMBAHASAN}

\section{Tingkat Pengungkapan Islamic Social Reporting (ISR)}

Berdasarkan perhitungan rata-rata nilai indeks ISR pada Tabel 1, peringkat perusahaan secara berurutan dimulai dari yang tertinggi adalah PT Indocement Tunggal Prakarsa Tbk (INTP), PT Indofood CBP Sukses Makmur Tbk (ICBP), PT Astra International Tbk (ASII), PT Indofood Sukses Makmur Tbk (INDF), PT Telekomunikasi Indonesia (Persero) Tbk (TLKM), PT Semen Indonesia (Persero) Tbk (SMGR), PT Unilever Indonesia Tbk (UNVR), PT Kalbe Farma Tbk (KLBF), PT United Tractors Tbk (UNTR), PT Astra Agro Lestari Tbk (AALI), PT PP London Sumatra Indonesia Tbk (LSIP), PT AKR Corporindo Tbk (AKRA), PT Lippo Karawaci Tbk (LPKR), dan PT Alam Sutera Realty Tbk (ASRI). Total poin yang diungkapkan perusahaan-perusahaan setiap tahunnya bervariatif, ada yang mengalami kenaikan, penurunan, ataupun konstan.

Tabel 1 Pengungkapan Islamic Social Reporting

\begin{tabular}{|c|c|c|c|c|c|c|c|c|c|}
\hline \multirow{3}{*}{$\begin{array}{c}\text { Nama } \\
\text { Perusahaan }\end{array}$} & \multicolumn{8}{|c|}{ Nilai yang Diungkapkan } & \multirow{3}{*}{$\begin{array}{l}\text { Rata-rata } \\
\text { indeks } \\
\text { per tahun }\end{array}$} \\
\hline & \multicolumn{2}{|c|}{2012} & \multicolumn{2}{|c|}{2013} & \multicolumn{2}{|c|}{2014} & \multicolumn{2}{|c|}{2015} & \\
\hline & Skor & Indeks & Skor & Indeks & Skor & Indeks & Skor & Indeks & \\
\hline AALI & 29 & 0.659 & 28 & 0.636 & 27 & 0.614 & 27 & 0.614 & 0.631 \\
\hline AKRA & 26 & 0.591 & 26 & 0.591 & 26 & 0.591 & 27 & 0.614 & 0.597 \\
\hline ASII & 32 & 0.727 & 32 & 0.727 & 33 & 0.750 & 33 & 0.750 & 0.739 \\
\hline ASRI & 15 & 0.341 & 22 & 0.500 & 22 & 0.500 & 22 & 0.500 & 0.460 \\
\hline ICBP & 32 & 0.727 & 33 & 0.750 & 33 & 0.750 & 33 & 0.750 & 0.744 \\
\hline INDF & 32 & 0.727 & 32 & 0.727 & 32 & 0.727 & 33 & 0.750 & 0.733 \\
\hline INTP & 34 & 0.773 & 33 & 0.750 & 32 & 0.727 & 33 & 0.750 & 0.750 \\
\hline KLBF & 30 & 0.682 & 29 & 0.659 & 29 & 0.659 & 30 & 0.682 & 0.670 \\
\hline LPKR & 22 & 0.500 & 22 & 0.500 & 24 & 0.545 & 27 & 0.614 & 0.540 \\
\hline LSIP & 29 & 0.659 & 26 & 0.591 & 28 & 0.636 & 26 & 0.591 & 0.619 \\
\hline SMGR & 31 & 0.705 & 31 & 0.705 & 33 & 0.750 & 31 & 0.705 & 0.716 \\
\hline TLKM & 32 & 0.727 & 32 & 0.727 & 31 & 0.705 & 32 & 0.727 & 0.722 \\
\hline UNTR & 29 & 0.659 & 29 & 0.659 & 29 & 0.659 & 29 & 0.659 & 0.659 \\
\hline UNVR & 31 & 0.705 & 31 & 0.705 & 32 & 0.727 & 32 & 0.727 & 0.716 \\
\hline
\end{tabular}

Sumber: Data diolah (2017) 
Pengungkapan ISR tertinggi dilakukan oleh perusahaan-perusahaan kategori manufaktur, dimana perusahaan tersebut memiliki potensi yang besar untuk memberikan dampak negatif terhadap lingkungan hidup. Dampak negatif yang dihasilkan oleh kegiatan operasional perusahaan dapat menyebabkan citra perusahaan menjadi kurang baik di masyarakat, sehingga mendorong terjadinya pengungkapan yang tinggi dari kegiatan CSR. Adapun yang termasuk perusahaan manufaktur adalah INTP, ICBP, ASII, INDF, SMGR, UNVR, dan KLBF. Akan tetapi, perusahaan TLKM menempati posisi tertinggi kelima dalam pengungkapan ISR, padahal TLKM bukan merupakan kategori perusahaan manufaktur. Hal yang menyebabkan pengungkapan ISR perusahaan TLKM tinggi adalah laporan keberlanjutannya menggunakan standar acuan. Perusahaan di Indonesia masih secara sukareka dalam membuat laporan keberlanjutan, namun wajib membuat laporan tahunan perusahaan.

Pada tahun 2012, perusahaan yang mendapatkan nilai indeks ISR tertinggi diraih oleh INTP, sedangkan yang mendapat skor terendah diduduki oleh ASRI. Pada tahun 2013, perusahaan yang mendapatkan nilai indeks ISR tertinggi diraih oleh ICBP dan INTP, sedangkan yang mendapat nilai indeks terendah diduduki oleh ASRI dan LPKR. Pada tahun 2014, perusahaan yang mendapatkan nilai indeks ISR tertinggi ada tiga, yaitu ASII, ICBP, dan SMGR. Adapun perusahaan dengan nilai indeks terendah masih diduduki oleh ASRI. Pada tahun 2015, perusahaan yang mendapatkan nilai indeks ISR tertinggi ada empat, yaitu ASII, ICBP, INDF dan INTP. ASRI masih menduduki posisi terendah dengan nilai indeks yang tidak berubah sebesar 0.341 .

\section{Analisis Deskriptif}

Berdasarkan Tabel 2, indeks ISR tertinggi sebesar 0.77 dan terendah sebesar 0.34 dengan nilai rata-rata sebesar 0.66 dan simpangan baku sebesar 0.09. Indeks ISR tertinggi diduduki oleh PT Indocement Tunggal Prakarsa Tbk (INTP) dengan skor sebesar 34 pada tahun 2012, sedangkan indeks ISR terendah diduduki oleh PT Alam Sutera Realty Tbk (ASRI) dengan skor sebesar 15 di tahun 2012. Nilai indeks ISR mendekati 1 menunjukkan bahwa suatu perusahaan telah melakukan pelaporan tanggung jawab sosial secara syariah.

Nilai umur perusahaan tertinggi sebesar 33 dan terendah sebesar 2 dengan nilai rata-rata sebesar 19 dan simpangan baku sebesar 7. Umur perusahaan tertinggi diduduki oleh PT Unilever Indonesia Tbk (UNVR) pada tahun 2015, sedangkan umur perusahaan terendah diduduki oleh PT Indofood CBP Sukses Makmur Tbk (ICBP) pada tahun 2012. Skor untuk jumlah dewan komisaris terendah sebesar 3 dan tertinggi sebesar 11 dewan. Jumlah dewan komisaris tertinggi dimiliki oleh PT Astra International Tbk (ASII) di tahun 2012, 2014, dan 2015. Sebaliknya, jumlah dewan komisaris terendah dimiliki oleh PT AKR Corporindo Tbk (AKRA) selama tahun 2012 sampai 2015.

Ukuran perusahaan memiliki nilai rata-rata sebesar 31.02. Ukuran perusahaan tertinggi diduduki oleh PT Astra International Tbk (ASII) dengan total aset sebesar Rp245 triliun di tahun 2015. Ukuran perusahaan terendah dimiliki oleh PT PP London Sumatra Indonesia Tbk (LSIP) dengan total aset senilai Rp7.55 triliun di tahun 2012. Nilai profitabilitas tertinggi sebesar 1.26 dan terendah sebesar 0.05. Nilai profitabilitas tertinggi dimiliki oleh PT Unilever Indonesia Tbk (UNVR) di tahun 2013, sedangkan nilai profitabilitas terendah diduduki oleh PT Lippo Karawaci Tbk (LPKR) di tahun 2015. Nilai leverage tertinggi sebesar 0.69 diduduki oleh PT Unilever Indonesia Tbk (UNVR) di tahun 2015 dan nilai leverage terendah sebesar 0.14 diduduki oleh PT Indocement Tunggal Prakarsa Tbk (INTP) di tahun 2013.

Tabel 2 Hasil analisis deskriptif

\begin{tabular}{ccccccc}
\hline & ISR & Age & DK & Size & Profit & Leverage \\
\hline Mean & 0.6640 & 19.1430 & 6.7321 & 31.0152 & 0.2498 & 0.4094 \\
Median & 0.6932 & 20.0000 & 7.0000 & 30.8455 & 0.1805 & 0.3956 \\
Max & 0.7727 & 33.0000 & 11.0000 & 33.1341 & 1.2581 & 0.6931 \\
Min & 0.3409 & 2.0000 & 3.0000 & 29.6528 & 0.0541 & 0.1364 \\
Std. Dev. & 0.0883 & 7.0670 & 1.8339 & 0.9542 & 0.2817 & 0.1675 \\
\hline
\end{tabular}

Sumber: Data diolah (2017) 


\section{Pemilihan Model Estimasi}

Berdasarkan Tabel 3, hasil Uji Chow menunjukkan bahwa nilai $\mathrm{F}$ hitung lebih besar dari $\mathrm{F}$ tabel (13.7424 > 2.00) sehingga tidak cukup bukti untuk menerima $\mathrm{H}_{0}$. Maka FEM lebih baik dibandingkan dengan CEM. Sementara itu, dari hasil uji Hausman dapat diperoleh bahwa nilai probabilitas sebesar 0.0472 lebih kecil dari alpha $0.05(0.047<0.05)$, sehingga $\mathrm{H}_{0}$ ditolak. Maka model yang tepat digunakan dalam penelitian ini adalah FEM.

Tabel 3 Hasil uji estimasi data panel

\begin{tabular}{lccl}
\hline \multicolumn{1}{c}{ Pengujian } & Statistik & Probabilitas & Hasil \\
\hline Uji Chow & 13.7424 & 0.0000 & FEM \\
Uji Hausman & 11.221 & 0.0472 & FEM \\
\hline Sumber: Data diolah (2017) & & &
\end{tabular}

\section{Uji Normalitas}

Uji normalitas data dapat dilakukan dengan melihat koefisien Jarque-Bera dan probabilitasnya. Apabila nilai probabilitas lebih besar dari $\alpha$, maka data berdistribusi normal. Tabel 4 menunjukkan bahwa nilai Jarque-Bera hitung sebesar 12.98547 lebih besar dari chi square table (12.98547 > 11.07048) sehingga $\mathrm{H}_{0}$ ditolak. Data dalam penelitian ini tidak berdistribusi normal. Akan tetapi, Nachowi dan Usman (2006) serta Gujarati dan Porter (2009) menyatakan bahwa normalitas bukan menjadi masalah yang terlalu berarti apabila ukuran sampelnya besar (lebih dari 30).

Tabel 4 Hasil uji normalitas

\begin{tabular}{lc}
\hline Jarque-Bera & Nilai \\
\hline Koefisien & 12.98547 \\
Probabilitas & 0.00151 \\
\hline
\end{tabular}

Sumber: Data diolah (2017)

\section{Uji Heteroskedastisitas}

Penelitan ini menggunakan Uji Park untuk mendeteksi heteroskedastisitas. Metode Uji Park adalah dengan meregresikan nilai logaritma natural dari residual kuadrat $\left(\right.$ Lnresid $^{2}$ ) dengan variabel independen. Berdasarkan Tabel 5 dapat diperoleh bahwa nilai signifikansi semua variabel bernilai lebih besar daripada alpha 0.05 sehingga $\mathrm{H}_{0}$ diterima. Begitu pula dari nilai t-hitung, bahwa nilai t-hitung semua variabel lebih kecil daripada nilai t-tabel sebesar 2.009 sehingga $\mathrm{H}_{0}$ diterima. Dengan demikian, dapat disimpulkan bahwa model regresi tidak terjadi masalah heteroskedastisitas.

Tabel 5 Hasil uji heteroskedastisitas

\begin{tabular}{lcc}
\hline Variabel & t-Statistik & Prob \\
\hline C & -0.787647 & 0.4359 \\
Age & -0.713422 & 0.4801 \\
DK & -0.848913 & 0.4014 \\
Leverage & -1.812967 & 0.0780 \\
Profitabilitas & -0.782539 & 0.4389 \\
Size & 0.843408 & 0.4044 \\
\hline
\end{tabular}

Variabel dependen: Lnresid $^{2}$

Sumber: Data diolah (2017)

\section{Uji Multikolineritas}

Multikolinearitas menandakan terdapat hubungan linier antarvariabel independennya. Uji multikolinieritas dilakukan dengan melihat nilai perhitungan koefisien korelasi sederhana antarvariabel 
bebasnya. Tabel 6 menunjukkan bahwa nilai koefisien korelasi antara variabel independen di bawah 0.8, maka dapat disimpulkan data dalam penelitian ini tidak terjadi masalah multikolineritas.

Tabel 6 Hasil uji multikolineritas

\begin{tabular}{lccccc}
\hline & Age & DK & Leverage & Profitabilitas & Size \\
\hline Age & 1.000000 & 0.025452 & -0.026859 & 0.476994 & 0.182449 \\
DK & 0.025452 & 1.000000 & -0.303699 & -0.263495 & 0.500764 \\
Leverage & -0.026859 & -0.303699 & 1.000000 & 0.382927 & 0.149810 \\
Profitabilitas & 0.476994 & -0.263495 & 0.382927 & 1.000000 & -0.203503 \\
Size & 0.182449 & 0.500764 & 0.149810 & -0.203503 & 1.000000 \\
\hline
\end{tabular}

Sumber: Data diolah (2017)

\section{Uji Autokorelasi}

Uji autokorelasi yang dilakukan dalam penelitian ini menggunakan metode Durbin-Watson (DW). Dari model regresi terbaik, yaitu FEM, dapat dilihat bahwa nilai DW dari persamaan regresi sebesar 2.2218. Adapun nilai tabel DW dengan $\mathrm{n}=56$ dan $\mathrm{k}=5$ adalah:

Tabel 7 Durbin-Watson

\begin{tabular}{cc}
\hline Keterangan & Nilai \\
\hline $\mathrm{dL}(56,5)$ & 1.3815 \\
$\mathrm{dU}(56,5)$ & 1.7678 \\
$4-\mathrm{Du}$ & 2.2322 \\
$4-\mathrm{Dl}$ & 2.6185 \\
$\mathrm{~d}-\mathrm{stat}$ & 2.2218 \\
\hline
\end{tabular}

Tabel 8 Hasil uji autokorelasi

\begin{tabular}{ll}
\hline Uji Autokorelasi & Nilai \\
\hline Korelasi positif & Antara $0-1.3815$ \\
Tidak dapat diputuskan & Lebih besar dari $1.3815-1.7678$ \\
& Lebih besar dari $2.2322-2.6185$ \\
Tidak ada korelasi & Lebih besar dari $1.7678-2.2322$ \\
Korelasi negatif & Lebih besar dari $2.6185-4$ \\
\hline
\end{tabular}

Sumber: Data diolah (2017)

Berdasarkan Tabel 7 dan 8 dapat disimpulkan bahwa nilai Durbin-Watson hitung sebesar 2.2218, lebih besar dari 1.7678 dan lebih kecil dari 2.2322 yang artinya tidak ada autokorelasi pada model regresi.

\section{Faktor-faktor yang Memengaruhi Pengungkapan ISR}

Analisis regresi dilakukan untuk menguji sejauh mana dan arah pengaruh variabel-variabel independen terhadap variabel dependen. Hasil regresi FEM dapat dilihat di Tabel 9. Berdasarkan hasil perhitungan, maka persamaan regresi linier berganda adalah:

$$
\text { ISR }=-6.324-0.023 \text { AGE }+0.002 \mathrm{DK}-0.361 \text { LEVERAGE }-0.141 \text { PROFIT }+0.245 \text { SIZE }
$$

Berdasarkan persamaan regresi di atas, dapat dilihat pengaruh masing-masing variabel independen terhadap variabel dependen. Konstanta persamaan regresi bernilai negatif sebesar 6.324, berarti jika nilai dari variabel-variabel independen sebesar 0 (konstan) maka nilai variabel dependen (ISR) sebesar -6.324. Koefisien regresi variabel umur perusahaan bernilai negatif sebesar 0.023 , artinya penurunan umur perusahaan sebesar satu satuan akan terjadi peningkatan pengungkapan ISR sebesar 0.023 dengan asumsi variabel independen lain konstan. Koefisien regresi variabel dewan komisaris bernilai positif sebesar 0.002, artinya peningkatan jumlah dewan komisaris sebesar satu satuan akan terjadi peningkatan pengungkapan ISR sebesar 0.002 dengan asumsi variabel independen lain konstan. 
Koefisien regresi variabel leverage bernilai negatif sebesar 0.361, artinya penurunan leverage sebesar satu satuan akan terjadi peningkatan pengungkapan ISR sebesar 0.361 dengan asumsi variabel independen lain konstan. Koefisien regresi variabel profitabilitas bernilai negatif sebesar 0.141, artinya penurunan profitabilitas sebesar satu satuan akan terjadi peningkatan pengungkapan ISR sebesar 0.141 dengan asumsi variabel independen lain konstan. Koefisien regresi variabel ukuran perusahaan bernilai positif sebesar 0.245 , artinya peningkatan ukuran perusahaan sebesar satu satuan akan terjadi peningkatan pengungkapan ISR sebesar 0.245 dengan asumsi variabel independen lain konstan.

Tabel 9 Hasil regresi Fixed Effect Model (FEM)

\begin{tabular}{lclll}
\hline \multicolumn{1}{c}{ Variabel } & Koefisien & Std. Error & t-Statistik & Prob. \\
\hline C & -6.324390 & 2.552812 & -2.477421 & 0.0179 \\
Age & -0.023393 & 0.011118 & -2.104131 & $0.0422^{*}$ \\
DK & 0.002034 & 0.008659 & 0.234915 & 0.8156 \\
Leverage & -0.360593 & 0.202396 & -1.781626 & $0.0830^{* *}$ \\
Profitabilitas & -0.140650 & 0.151249 & -0.929925 & 0.3584 \\
Size & 0.245211 & 0.091191 & 2.688973 & $0.0107^{*}$ \\
\hline$R$-squared & 0.934023 & Adjusted R-squared & 0.901926 \\
DW statistik & 2.221836 & Prob (F-statistik) & 0.000000 \\
\hline
\end{tabular}

Ket: Tanda * signifikansi pada taraf nyata $5 \%$

Tanda ** signifikansi pada taraf nyata $10 \%$

Sumber: Data diolah (2017)

Uji statistik F digunakan untuk menguji signifikansi parameter regresi secara simultan. Uji statistik F menunjukkan apakah semua variabel independen yang dimasukan dalam model mempunyai pengaruh secara bersamaan terhadap variabel dependen. Berdasarkan hasil Tabel 9 keluaran model regresi FEM, nilai signifikasi sebesar 0.000 kurang dari 0.05 , artinya secara bersama-sama variabel umur perusahaan, dewan komisaris, leverage, profitabilitas, dan ukuran perusahaan berpengaruh signifikan terhadap pengungkapan ISR.

Uji t digunakan untuk mengetahui apakah variabel independen secara parsial memengaruhi variabel dependen. Nilai t-hitung umur perusahaan sebesar -2.104 dan nilai probabilitas sebesar $0.042<0.05$. Hal ini menunjukkan pengaruh umur perusahaan terhadap pengungkapan ISR adalah negatif dan signifikan pada taraf nyata 5\%. Hasil temuan ini didukung penelitian lain oleh Oktavianti dan Wahidahwati (2014). Penelitian ini membuktikan bahwa pendeknya umur suatu perusahaan tidak berpengaruh terhadap rendahnya pengungkapan ISR namun dapat meningkatkan pengungkapan tersebut, salah satu contohnya adalah PT Indofood CBP Sukses Makmur Tbk (ICBP). Perusahaan ini di tahun 2015 baru berusia lima tahun, tetapi jumlah poin yang diungkapkan setara dengan perusahaan yang berusia 26 tahun. Hal ini dapat disebabkan karena ICBP merupakan anak perusahaan dari PT Indofood Sukses Makmur Tbk (INDF) yang usia perusahaan tersebut empat kali usia ICBP, sehingga format pelaporan tanggung jawab sosial kedua perusahaan sama. Selain itu, Ulum (2009) menyatakan bahwa suatu perusahaan dapat mengalami semangat reputation driven, yaitu motivasi untuk mendongkrak citra perusahaan dan menjadi perusahaan ternama dalam perdagangan pasar saham meskipun perusahaan tersebut baru di kancah pasar modal.

Nilai t-hitung jumlah dewan komisaris sebesar 0.235 dan nilai probabilitas sebesar $0.816>0.05$. Hal ini menunjukkan pengaruh jumlah dewan komisaris terhadap pengungkapan ISR adalah tidak signifikan. Temuan ini membuktikan bahwa sedikit atau banyaknya jumlah dewan komisaris di suatu perusahaan tidak akan memengaruhi pengungkapan tanggung jawab sosial perusahaan secara luas. Sejalan dengan penelitian Khoirudin (2013) bahwa ukuran dewan pengawas syariah tidak berpengaruh terhadap pengungkapan Islamic Social Reporting perbankan syariah di Indonesia. Karena dewan komisaris dan dewan syariah tidak ikut campur dalam pengambilan keputusan yang bersifat operasional. 
Nilai t-hitung leverage sebesar -1.782 dan nilai probabilitas sebesar $0.083>0.05$. Hal ini menunjukkan pengaruh leverage terhadap pengungkapan ISR adalah negatif dan signifikan pada taraf nyata $10 \%$. Temuan ini telah sesuai dengan hipotesis dan teori penelitian bahwa suatu perusahaan yang memiliki utang kecil akan memengaruhi keputusannya dalam meningkatkan pelaporan kinerja sosial secara syariah.

Nilai t-hitung profitabilitas sebesar -0.930 dan nilai probabilitas sebesar $0.358>0.05$. Hal ini menunjukkan pengaruh profitabilitas terhadap pengungkapan ISR adalah tidak signifikan. Temuan ini didukung penelitian sebelumnya oleh Haniffa (2002). Suatu perusahaan yang menunjukkan kepatuhannya terhadap syariah akan lebih jujur dan transparansi dalam memberikan informasi kegiatan operasional mereka kepada masyarakat meskipun perusahaan tersebut memiliki keuntungan yang kecil, besar, atau tidak sama sekali.

Nilai t-hitung ukuran perusahaan sebesar 2.689 dan nilai probabilitas sebesar $0.011<0.05$. Hal ini menunjukkan pengaruh ukuran perusahaan terhadap pengungkapan ISR adalah positif dan signifikan pada taraf nyata 5\%. Temuan ini telah sesuai dengan hipotesis dan teori penelitian bahwa semakin besar jumlah aset suatu perusahaan maka semakin tinggi pengungkapan kinerja sosial perusahaan tersebut secara syariah.

Analisis koefisien determinasi $\left(\mathrm{R}^{2}\right)$ digunakan untuk mengetahui persentase variabel-variabel independen terhadap variabel dependen. Berdasarkan Tabel 9 keluaran REM, nilai R-square sebesar 0.934, artinya secara bersama-sama variabel umur perusahaan, dewan komisaris, leverage, profitabilitas, dan ukuran perusahaan mempunyai kontribusi menjelaskan pengungkapan Islamic Social Reporting sebesar 93.4\%, sedangkan sisanya sebesar 6.6\% dijelaskan oleh variabel lain yang tidak diteliti atau tidak dimasukan dalam model penelitian ini.

\section{PENUTUP}

\section{Simpulan}

Berdasarkan perhitungan rata-rata nilai indeks ISR, peringkat perusahaan secara berurutan dimulai dari yang tertinggi adalah INTP, ICBP, ASII, INDF, TLKM, SMGR, UNVR, KLBF, UNTR, AALI, LSIP, AKRA, LPKR, dan ASRI. Pengungkapan ISR tertinggi dilakukan oleh perusahaan-perusahaan kategori manufaktur, dimana perusahaan tersebut memiliki potensi yang besar untuk memberikan dampak negatif terhadap lingkungan hidup. Adapun yang termasuk perusahaan manufaktur adalah INTP, ICBP, ASII, INDF, SMGR, UNVR, dan KLBF. Akan tetapi, perusahaan TLKM menempati posisi tertinggi kelima dalam pengungkapan ISR, padahal TLKM bukan merupakan kategori perusahaan manufaktur. Hal yang menyebabkan pengungkapan ISR perusahaan TLKM tinggi adalah laporan keberlanjutannya menggunakan standar acuan.

Variabel yang berpengaruh signifikan secara negatif terhadap pengungkapan Islamic Social Reporting adalah umur perusahaan dan leverage. Variabel ukuran perusahaan berpengaruh positif signifikan terhadap pengungkapan Islamic Social Reporting. Adapun variabel lainnya, seperti jumlah dewan komisaris dan profitabilitas menunjukkan pengaruh yang tidak signifikan terhadap pengungkapan Islamic Social Reporting.

\section{Saran}

Berdasarkan hasil penelitian, maka saran yang dapat diberikan adalah sebagai berikut:

1 Perusahaan-perusahaan di Indonesia, khususnya manufaktur dapat membuat laporan keberlanjutan dengan standar ISR sebagai bentuk tanggung jawab kepada masyarakat akibat kegiatan operasional yang cenderung memberikan dampak negatif terhadap lingkungan.

2 Pemerintah diharapkan dapat menegakkan peraturan mengenai CSR bagi perusahaan yang terdaftar dalam efek syariah sehingga indeks Islamic Social Reporting lebih berkembang luas dengan indikator-indikator yang telah disepakati dan ditetapkan oleh regulasi. 
3 Saran untuk penelitian selanjutnya adalah melakukan komparasi pengungkapan ISR antara perusahaan manufaktur dengan perbankan syariah, serta penambahan variabel independen yang lebih Islami, sehingga dapat menggambarkan kontinuitas faktor yang relevan terhadap pengungkapan laporan tanggung jawab sosial secara syariah.

\section{DAFTAR PUSTAKA}

Adelopo, I. (2011). Voluntary disclosure practices among listed companies in Nigeria. Advances in Accounting, 27(2), 338-345.

[AICPA] American Institute of Certified Public Accountants (1994). Improving Business Reporting A Customer Focus: Meeting the Information Needs of Investors and Creditors. Comprehensive Report of the Special Committee on Financial Reporting. New York (US), American Institute of Certified Public Accountants.

Ambadar, J. (2008). Corporate Social Responsibility: Dalam Praktek di Indonesia, Wujud Kepedulian Dunia Usaha. Jakarta (ID), PT Elex Media Komputindo.

Andrikopoulos, A., Samitas, A., \& Bekiaris, M. (2014). Corporate social responsibility reporting in financial institutions: Evidence from Euronext. Research in International Business and Finance, $32,27-35$.

Darus, F., Fauzi, H., Purwanto, Y., Yusoff H, Amran, A., Zain, M.M., Naim, D.M.A., \& Nejati, M. (2014). Social responsibility reporting of Islamic banks: Evidence from Indonesia. Int. J. Business Governance and Ethics, 9(4), 356-380.

Diamond, D. (1991). Monitoring and reputation: The choice between bank loans and directly placed debt. Journal of Political Economy, 99(4), 689-721.

El Halaby, S. \& Hussainey, K. (2015). The determinants of social accountability disclosure: Evidence from Islamic banks around the world. International Journal of Business, 20(3), 202-223.

Farook, S., Hassan, M.K., \& Lanis, R. (2011). Determinants of corporate social responsibility disclosure: The case of Islamic banks. Journal of Islamic Accounting and Business Research, 2(2), 114-141.

Fitria, S. \& Hartanti, D. (2010). 'Islam dan Tanggung Jawab Sosial: Studi Perbandingan dan Pengungkapan Berdasarkan Global Reporting Initiative Indeks dan Islamic Social Reporting Indeks'. Simposium Nasional Akuntansi XIII Purwokerto, 1-33.

Gujarati, D.N. \& Porter, D.C. (2009). Basic Econometrics Fifth Edition. Singapura (SG), McGrawHill.

Haniffa, R. (2002). Social reporting disclosure an Islamic perspective. Indonesian Management and Accounting Research, 1(2), 128-146.

Hikmah, N., Chairina, \& Rahmayanti, D. (2011). 'Faktor-faktor yang Mempengaruhi Luas Pengungkapan Corporate Governance dalam Laporan Tahunan Perusahaan Perbankan yang Terdaftar di Bursa Efek Indonesia'. Simposium Nasional Akuntansi XIV.

Jensen, M. \& Meckling, W.H. (1976). Theory of the firm: Managerial behavior, agency costs, and ownership structure. Journal of Financial Economics, 3(4), 305-360.

Khoirudin, A. (2013). Corporate governance dan pengungkapan Islamic Social Reporting pada perbankan syariah di Indonesia, Accounting Analysis Journal, 2(2).

Lestari, P. (2013). Determinants of Islamic Social Reporting in syariah banks: Case of Indonesia. International Journal of Business and Management Invention, 2, 28-34.

Maali, B., Casson, P., \& Napier, C. (2006). Social reporting by Islamic banks. Abacus, 42(2), 266-289.

Mallin, C., Faraga, H., Ow-Yong, K. (2014). Corporate social responsibility and financial performance in Islamic banks. Journal of Economic Behavior \& Organization, 103, S21-S38.

Marwata (2001). 'Hubungan Antara Karakteristik Perusahaan dan Kualitas Ungkapan Sukarela dalam Laporan Tahunan Perusahaan Publik di Indonesia'. Simposium Nasional Akuntansi IV, 155-173.

Merina, C.I. \& Verawaty (2016). Analisis komparasi indeks Islamic Social Reporting perusahaan perbankan syariah dan perusahaan go public yang listing di Jakarta Islamic Index. AKUISISI, 12(2), 1-17. 
Nachrowi, N.D. \& Usman, H. (2006). Pendekatan Populer dan Praktis Ekonometrika untuk Analisis Ekonomi dan Keuangan. Jakarta (ID), Lembaga Penerbit Fakultas Ekonomi Universitas Indonesia.

Naser, K. \& Hassan, Y. (2013). Determinants of corporate social responsibility reporting: Evidence from an emerging economy. Journal of Contemporary Issues in Business Research, 2(3).

Nobanee, H. \& Ellili, N. (2015). Corporate sustainability disclosure in annual reports: Evidence from UAE banks: Islamic versus conventional. Renewable and Sustainable Energy Reviews, 55, 13361341.

Oktavianti, H. \& Wahidahwati (2014). Faktor-faktor yang memengaruhi pengungkapan intellectual capital. Jurnal Ilmu dan Riset Akuntansi, 3(5), 1-18.

Omar, B. \& Simon, J. (2011). Corporate aggregate disclosure practices in Jordan. Advances in Accounting, 27(1), 166-186.

Othman, R., Thani, A.M. \& Ghani, E.K. (2009). Determinants of Islamic Social Reporting among topshariah approved companies in Bursa Malaysia. Research Journal of International Studies, 12(10), 4-20.

Platonova, E., Asutay, M., Dixon, R., \& Mohammad, S. (2018). The impact of corporate social responsibility disclosure on financial performance: Evidence from the GCC Islamic banking sector. J. Bus. Ethics, 151(2), 451-471.

Purnomosidhi, B. (2006). Praktik pengungkapan modal intelektual pada perusahaan publik di BEJ. Jurnal Riset Akuntansi Indonesia., 9(1), 1-19.

Rahman, A.A. \& Bukair, A.A. (2013). The influence of the shariah supervision board on corporate social responsibility disclosure by Islamic banks of Gulf Co-Operation Council Countries. Asian Journal of Business and Accounting, 6(2).

Rama, A. \& Meliawati. (2014). Analisis determinan pengungkapan Islamic Social Reporting: Studi kasus bank umum syariah di Indonesia. Equilibrium, 2(1).

Saidi, Z. \& Abidin, H. (2004). Menjadi Bangsa Pemurah: Wacana dan Praktek Kedermawanan Sosial di Indonesia. Jakarta (ID), Piramedia.

Sudana, I.M. (2011). Manajemen Keuangan Teori dan Praktik. Jakarta (ID), Erlangga.

Sudarsono, H. (2003). Bank dan Lembaga Keuangan Syariah: Deskripsi dan Ilustrasi. Yogyakarta(ID), Ekonisia.

Suhardjanto, D. \& Wardhani M. 2010. Praktik intellectual capital disclousure perusahaan yang terdaftar di Bursa Efek Indonesia. JAAI, 14(1).

Ulum, I. (2009). Intellectual Capital: Konsep dan Kajian Empiris Ed ke-1. Yogyakarta (ID), Graha Ilmu.

White, G., Alina, L., \& Greg, T. (2007). Drivers of voluntary intellectual capital disclosure in listed biotechnology companies. Journal of Intellectual Capital, 8(3), 517-537.

Widarjono, A. (2007). Ekonometrika: Teori dan Aplikasi untuk Ekonomi dan Bisnis Ed ke-2. Yogyakarta (ID), Ekonisia.

Wulan, M. \& Anggraini, A. (2015). Faktor financial-non financial dan tingkat pengungkapan Islamic Social Reporting. Jurnal Akuntansi dan Keuangan Islam, 2(2), 161-184.

Zweibel, J. (1996). Dynamic capital structure under managerial entrenchment. The American Economic Review, 86, 1197-1215. 